\title{
Hybrid variations on a documentary theme
}

Robert Stam'

I É professor transdisciplinar da Universidade de Nova York. Autor de diversos livros sobre cinema e literatura, cinema e estudos culturais, incluindo Brazilian cinema, Reflexivity in film and literature, Subversive pleasure, Tropical multiculturalism, Film theory: an introduction, Literature through film e François Truffaut and friends. Formado pela Universidade da Califórnia, Berkeley, também frequentou a Universidade de Paris III. Lecionou na Tunísia, na França e no Brasil (USP, UFF, UFMG) E-mail: rps l @nyu.edu 


\section{Resumo}

Embora muitas vezes encarado como pólos opostos, o documentário e a ficção são, na verdade, teórica e praticamente entrelaçados, assim como a história e a ficção, também convencionalmente definidos como opostos, são simbioticamente ligados. $\mathrm{O}$ historiador Hayden White argumentou em seu livro Metahistory que a distinção mito/ história é arbitrária e uma invenção recente. No que diz respeito ao cinema, bem como à escrita, White apontou que pouco importa se o mundo que é transmitido para o leitor/espectador é concebido para ser real ou imaginário, a forma de dar sentido discursivo a ele através do tropos e da montagem do enredo é idêntica (WHITE, 1973). Neste artigo, examinaremos as maneiras que a hibridação entre documentário e ficção tem sido mobilizada como radical recurso estético.

\section{Palavras-chave}

Documentário, ficção, hibridização, sentido discursivo.

\section{Abstract}

Although often assumed to be polar opposites, documentary and fiction are in fact theoretically and practically intermeshed, just as history and fiction, also conventually seen as opposites, are symbiotically connected. Historian Hayden White argued in Metahistory that the myth/history distinction was arbitrary and of recent invention. In words that apply to film as well as to writing, White pointed out that it matters little whether the world that is conveyed to the reader/spectator is conceived to be real or imagined; the manner of making discursive sense of it through tropes and emplotment is identical (WHITE, 1973). In this article, we will examine the ways that the hybridization of documentary and fiction has been mobilized as a radical aesthetic resource.

\section{Keywords}

Documentary, fiction, hybridization, discursive sense. 


\section{The fiction-documentary continuum}

Jacques Derrida's claims about genre in general in "The Law of Genre" apply equally to documentary and fiction: "The trait which marks membership inevitably divides, the boundary of the set comes forth, by invagination, an internal pocket larger than the whole; and the outcome of this division and of this abounding remains as singular as it is limitless" (1988: 206). As transgenres incorporating myriad subgenres, documentary and fiction allow for an infinity of permutational crossings and variations. It is revealing, in this sense, that some spectators mistakenly refer to films like City of God or Entre les Murs as "documentaries," when in fact they are staged films that deploy documentary-effects, i.e., the mimicry of the documentary style through the use of non-actors, hand-held camera, and blurred footage. The proliferation of syncretizing coinages such as "documenteur" (the title of an Agnés Varda film), "fiction documentaire" (Jacques Rancière [2001: 201]), and "reality fictions" (Frederick Wiseman), also testify to the burgeoning hybridization of the two modes. Rather than see documentary and fiction as distinct generic essences, we might better distinguish, with Roger Odin, between fictionalizing and documentarizing modes and between documentary and fictive operations (ODIN, 2000).

Christian Metz famously argued that all films, in that they all involve arrangement and mediation, are fiction films. Yet the converse is also true; all films are arguably documentaries in that they document something, even if only the changing modes of production and performance at a given point in time. In this sense, all films form what David James calls allegories of cinema - filmic registers of their own modes of production and their own shaping of social relations (JAMES, 1989). What, then, constitutes the documentary difference? For some, a higher coefficient of ethical responsibility distinguishes the two modes: documentary representations, existing on a continuum with 
real life, have practical and ethical consequences for the "characters." For Vivian Sobchack, documentary is "constituted and inscribed as ethical space: it stands as the objectively visible evidence of subjective visual responsiveness and responsibility for a world shared with other subjects" (2004: 248). For Jean-Louis Commoli, documentaries submit to the "risk of the real," i.e., they are shadowed and nourished by the vicissitudes of production and of actuality. That risk can take very brutal form - as with the coup d'etat that interrupted the filming of The Battle of Chile and led to the murder of the film's cameraman and the exile of the director ${ }^{2}-$ or take the less dramatic form of mutual insecurity. In documentary interlocution, for Comolli, the anxieties of the filmmaker at the moment of filming meet the anxieties of the filmed subject at the moment of being filmed, while each risks becoming "other" to themselves COMOLLI, 2008).

The hybridization of documentary and fiction is hardly new. Apart from filmmakers like J. Stuart Blackton, who filmed Spanish-American Caribbean wars in New Jersey bathtubs, even a cursory look at film history reveals a wide spectrum of practices, with gradations rather than fixed lines. Citizen Kane was based on a historical prototype (Hearst) and begins with a semi-parodic fake newsreel ("News on the March"). Both Hitchcock's The Wrong Man and Buñuel's Los Olvidados were based on journalistic reportage and filmed in black-and-white documentary style. A number of aesthetic practices in the 1960s and 1970s, such as "expanded cinema," sought to destabilize hierarchies and boundaries of medium specificity. ${ }^{3}$ Contemporaneously, the various New Waves - Neo Realism, the Nouvelle Vague, Cinema Novo, New German Cinema - injected documentary elements into fiction films as a means of formal renovation. Conversely, the French ethnographer/filmmaker Jean Rouch injected fictive elements into documentary leaving, as Rouch put it, "almost no boundary between documentary film and films of fiction" (apud AUFERDEIDE, 2007:

2. On risk in the cinema, see HJORT, Mette. Film and Risk. Detroit: Wayne State University Press, 2012.

3. See YOUNGBLOOD, Gene. Expanded Cinema. New York: P. Dutton \& Co., 1970 and KAPROW, Allan. Assemblage, environments \& happenings. New York : H.N. Abrams, 1966. 
ano 2 número 4

Dossiê

112). His La Pyramide Humaine stages a fictive psychodrama about racial divisions in a French lycée in Abidjan, but the fiction generated very real consequences such as friendships and quarrels, love affairs and breakups. For Rouch, advance-plotted psychodramas were a way of "lying to tell the truth" by using fiction to open up reality to risk and adventure. Rouch wielded the camera as a catalyst capable of provoking personal transformations through the filmic experience. ${ }^{4}$ Initially contrived psychodramatic situations, in his view, could become filmic therapy triggering positive changes in the form of more equal and convivial social relations.

Edgar Morin, together with Jean Rouch, coined the term cinéma vérité - a translation of Vertov's Kino Pravda ("cinema-truth," but in the Russian context also "cinema-newspaper") - to refer to a documentary process that reflexively foregrounds the actual processes of making of the film. Cinéma vérité was often contrasted with direct cinema (also known as observational cinema), i.e., "fly-on-the-wall", non-reflexive filmmaking taking advantage of light-weight cameras and synchronous sound to record social life as accurately as possible. Yet Frederick Wiseman, the filmic anatomist of what might be called institutional micropolitics - observational critiques of social institutions like asylums, prisons, hospitals, universities, and so forth - has long labeled his films reality fictions, where documentary is "just another form of fiction." ${ }^{5}$ Linda Williams, meanwhile, has proposed the term "antiverité" to refer to films that eschew realistic recording life-as-it-is in favor of "a deeper investigation of how it became as it is" (apud DAY, 2011, p. 112).

For Comolli, cinema generally has been endlessly enriched by the cross-play of fiction and documentary (2012: 65). To documentarize fiction is in some ways to democratize it, given that documentary has historically been more socially inclusive than the fiction feature. Through reciprocal chameleonism, the two trans-genres come to resemble one another. Mutual enrichment occurs

\footnotetext{
4. Brian Winston calls Chronique the "totemic ancestor" of Reality TV shows such as Wife Swap (WINSTON, 2007).
}

5. http://www.current.org/doc/doc802wiseman.shtml 
when directors mingle the two modes through thespian hybridity or the insertion of actors into the stream of real life and real-life situations. Haskell Wexler's Medium Cool plunged its actors into the maelstrom of the protests at the 1968 Democratic Convention in Chicago. The Brazilian film Iracema (1975), set in the Amazon region, meanwhile, pairs two players of very different status and experience, one a famous white actor (Paulo Cesar Pereio) playing a truckdriver, the other an unknown indigenous beginner (Edna de Cassia) playing a prostitute, as a strategy for charting unequal relations of power. In a spoof on directorial megalomania, John Smith's The Girl Chewing Gum (1976) simply registers activities on a busy London street, but has Smith's voice-over shout out instructions to the traffic and passersby, maniacally "directing" the "actors" in the pre-existing footage.

Eduardo Coutinho's Jogo de Cena (Playing), meanwhile, has actresses and "real people" recite the same lines of dialogue, within a strategy of disorientation where the spectator loses track of what is individual recollection and what is performative enactment. Both actress and non-actress "break frame" and comment on their "performance." In a transpersonal continuity, one "performer" picks up where the other left off. The manufactured tears or the professional actress (Marilha Pera) turn into real tears when she thinks of her own daughter. Coutinho facilitates the self-fabulation of the characters, a process which Deleuze, in a different context, calls "the becoming of real characters when they begin to fictionalize themselves and thus contribute to the invention of a people" (1985: 195-196). Within Coutinho's theatrum mundi ("theatre of the world"), the limits of theatre and world, as in Brechts's "ever yday theatre of the street," become subject to a provocative destabilization.

The melding of fiction and documentary can generate non-fiction films every bit as suspenseful as the best fiction films. Through a stratagem that might be called sequestering suspense or highjacking Hitchcock, José Padilha's documentary Ônibus 174 turns the real-life highjacking of a Brazilian bus by a homeless street person named Sandro into a sociological thriller. Since Brazilians knew the outcome from the media due to saturation coverage police mistakenly killed one of the passengers, and later killed Sandro - the 
ano 2 número 4

Dossiê

film downplays suspense in the conventional sense, exploring instead the human backstories and social implications of the event. What would make a person like Sandro sequester a bus? In a kind of outtake juijitsu, Padilha used Globo Network outtakes - reinvoiced through commentary and supplemented with interviews - to expose the superficiality of Globo's own portrayals. Repeatedly abused by the police, Sandro, we learn, had been an eyewitness to the police murder of street children in the notorious 1995 Candelária massacre. Directly addressing the police, he shouts “Look at my face! Take a good look!" and denounces police violence. Sandro becomes the disturbed yet eloquent spokesperson for the victims of the police and the prison system. Rather than merely register events, Onibus 174 exposes the ideological blinders through which the media usually relay violent incidents. But even more remarkably, the film's narrative structure strongly resembles that of certain Hitchcock films, which proceed via a double temporal movement - a narrative forward zoom combined with a backward dolly, as it were - in that the story simultaneously moves forward in terms of the unfolding events in the sequestered bus and backward, toward the origin of a trauma. Much as Hitchcock traces the origins of Gregory Peck's amnesia in Spellbound, or of Marnie's kleptomania in Marnie, Padilha traces the social origins of Sandro's trauma.

\section{Murderous reenactments}

The ever-more audacious mixing of fact and fiction in documentaries becomes especially evident in the realm of reenactment. A number of recent documentaries, such as S-21, The Khmer Rouge Killing Machine, and El Sicario, Room 164 - get murderers to reenact their crimes. Joshua Oppenheimer's The Act of Killing (2013) is especially daring in this sense, in that the director induced mass-killers, in a kind of reenactment as self-indictment, to restage their own murders in their own way. The most powerful and irrefutable indictment, after all, is that which comes not from the prosecutors but from the perpetrators themselves. The protagonist of the film is Anwar Congo, a thug deeply involved in the 1965-1966 genocide that murdered at least a million people and swept General Suharto into power. As the head of the 
"Frog Squad," Congo killed roughly a thousand souls with his own hands. Since the current government traces its origins to that genocide, no one has been jailed for these crimes; in fact, people like Congo have been feted as national heroes, and even applauded, as we see, on popular Indonesian talkshows. Congo had every reason to believe that the film would celebrate his "feats" since celebration of such feats formed part of the official narrative.

The death squad members offer a toxic brew of racism (toward the Chinese), machismo (toward women), sadism (toward everyone), phobic anti-communism (toward political enemies), homoerotic homophobia (through bellicose male bonding), and sheer love of orgiastic mayhem. To gain access to his subjects, Oppenheimer exploited their love of Hollywood-style entertainment. Using strategic mendacity, he proposed a fiction film where they would play their own roles, within the sensational codes of their most adored genres -- the western, the gangster film, and Elvis Presley musicals. (The thugs were known as "movie theatre gangsters" who would hang out in their favorite cinemas). By inviting the killers to recreate the murders in a Hollywoodean style, Oppenheimer highlights the role of mass-mediated phantasy both in the crimes themselves and in the reenactments of those crimes. Various sequences are staged in the manner of a western (with the killers in cowboy hats) or as horror, or as a musical, as when dancers writhe by a waterfall to "Born Free." For these movie-fed gangsters, Hollywood offered an ethos, an acting school, and audiovisual training in torture techniques.

There is of course a canonical precedent for theatrical self-indictment, in the mousetrap strategy of the play-within-the-play in Hamlet, set to "catch the conscience of a king." But in this instance it is as if Claudius had set the mousetrap himself and had himself reenacted his murder of Hamlet's father. (The film's title also recalls Hamlet's constant play with theatrical metaphors "you who are witnesses to this act.") Congo reenacts his misdeeds with gusto and a strange pride. In a kind of fascist lehrstucke, he demonstrates, on the very roof where he had committed the crimes, his favored technique of wire-strangling as a way of avoiding too much blood. Out of some inverted narcissism or Dostoyevskian impulse, Congo revisits the scene of the crime and acknowledges everything - the false charges against 
ano 2 número 4

Dossiê

the victims, the gratuitous cruelty, the imaginative sadism- and seems to be eager for the audience, including his grandchildren, to see the reenactments. Throughout, Congo remains cheerful, supposedly exulting in his 90 minutes of movie fame. ${ }^{6}$

Indeed, what most disturbs in The Act of Killing is the Tarantino-style nonchalance of the killers. While immoral, these lumpen übermenschen are not stupid: they use words like "sadistic" and exhibit a knowledge of Hollywood genre films worthy of a film scholar. Instead of the "banality of evil" that Hannah Arendt discerned in the insipid bureaucrat Eichmann, The Act of Killing reveals the charm of evil, that of a dapper bon vivant who loves animals, his grandchildren, and the cha-cha-cha. The film is deeply unsettling because it leaves no comfortable place for the spectator. Within the film's immanent critique, no one directly voices the human values we assume to motivate the filmmaker; no one gives voice to ethical normativity. While the film could be faulted for not emphasizing the perspective of the victims and for not showing resistance to the regime - a perception that could feed into Orientalist preconceptions about the "despotic East" - the film's entrapment strategy ultimately also serves the interest of the victims. ${ }^{7}$ The film immerses us in Congo's upside-down world of socially sanctioned immorality - extortion is normal, rape is fun, human rights are bad, murder is divine - yet the film shows that we are also tempted to like him. Nor are enlightened western spectators as separated from his misdeeds as they might like to think. For decades Americans indirectly supported, through their taxes and their compliance, many such "anticommunist" regimes in places like Chile, Argentina, Viet Nam, South Africa, and Iran, and the still-living architects of those policies are treated reverentially on American TV talk-shows.

Tacit norms of humanity do emerge in subtle ways in the film. When we see peasants reenact the massacres that took place in their own village -

6. Oppenheimer had to become a bit of an actor himself by maintaining his composure in the face of the crimes being reenacted. Were his ruse to be discovered, he could easily be expelled from the country, while the collaborating technicians - listed in the final credits as "anonymous" - could suffer terrible consequences.

7. Robert Stam expresses his appreciation to Yemane Demissie for his critical insights concerning the film. 
rather like the Sioux prodded by Hollywood to reenact the Wounded Knee massacre - they look absolutely terrified even after the director says "cut!" Certain questions from the (unseen) director, similarly, imply a certain moral standard. Many of the most important cues are non-verbal, however, having to do with the arc of emotion as revealed by the expressive body. Congo's body language and expression seems to move slowly from exuberance to doubt to a certain melancholy, depression, and even nausea. A clear crack in his psychic armor appears when he briefly plays the victim of torture and is thus obliged to imagine a tiny portion of the pain and humiliation suffered by his own victims. “Do you think those people," he asks Oppenheimer, "felt like I did when I played their role?" Even more dramatic is the near final scene where Congo, in a kind of visceral karma, writhes with a severe case of the dry heaves. It is hard not to read the moment as an instance of failed catharsis, an abortive attempt to purge massive guilt. Without these ephemeral glimpses of doubt and answerability, the film would have been quite simply intolerable, resulting in a kind of triple horror: the horror of the crimes themselves, the horror in knowing that the criminals were never punished, and the horror of knowing that they felt little remorse. Although one death squad member points out that "history is written by the winners," at least for one moment Oppenheimer has tricked one of the "winners" of history to imagine - however briefly - the feelings of history's "losers." (The film is currently being used by activists in Indonesia, and Oppenheimer plans to make a sequel from the point of view of the victims).

\section{From representation to self-presentation}

Paulo Sacramento's feature documentary Prisioneiro das Grades de Ferro (2003) brings up key political/aesthetic issues of voice and representation. While preparing to make the film, Sacramento realized that his pampered background did not prepare him for the task. To get to know the prison, he offered filmmaking training to both the guards and the prisoners, but since only the latter were interested, they ended up being the co-directors of the film. 
ano 2 número 4

Dossiê

Bakhtin's characterization of literary texts as taking place on "interindividual territory," while true of all films as involving collaboration, is even more apt for a film like Prisioneiro. The subtitle reveals the film's intention: rather than portraits of the prisoners, we have self-portraits. Instead of characters in search of an auteur, we have prisoner-characters as co-authors of their own portrait. The film is premised on a kind of subject-director contract based on complementary knowledges; while the filmmaker initiates the prisoners into the codes of filmmaking, the prisoners initiate the filmmaker into the codes of the prison. The film thus breaks with what Jean-Claude Bernardet calls the "sociological documentary," where "experts" speak in "voice-of God" narration about the socially excluded while reaffirming their own power and authority (2003: 15).

Sacramento avoids the trap of the appropriation of speech through hybrid authorship or, in Foucauldian terms, "speaking together" instead of "speaking for." It was in conjunction with his work with the GIP (Prison Information Group), after all, that Foucault came to speak of "the indignity of speaking for others." The film in this sense undercuts the usually asymmetrical power relations between director and subject, a relation which becomes even more overwhelmingly asymmetrical in the case of those suffering the "social death" of incarceration. Hybrid authorship becomes a partial solution, then, to the aporias of subaltern speech (Gayatri Spivak), or the problematic nature of authentic, unmediated self-representation by oppressed and marginalized groups powerless to shape their own representation.

Prisioneiro das Grades de Ferro practices authorial self-relativization or the subversion of directorial power through a suggestive array of mechanisms: 1) the transfer of expertise by which the prisoners themselves become the real experts, those best equipped to reveal the secret codes, power arrangements, and political economy of the prison; 2) the dispersive delegation of mise-enscène, by which the prisoners register scenes that Sacramento could not possibly have filmed, such as scenes from inside the cells at night; and 3) the inversion of the panoptical gaze, so that we do not look at the prisoners through the 
peephole like the guards (or like Varela in the Babenco film); rather we look with the prisoners looking at the guards looking through the peephole.

Finally, the film practices humanization through domestication by showing the prisoners in their cells, which they have remodeled into simulacra of home through their own mise-en-scène of personal artifacts. Centralizing the peripheralized, the film creates a kind of self-subjectification through carceral phenomenology. Rather like Juliette in 2 or 3 things I know about Her, the prisoners become the phenomenologists of their own lives. As they reflect on the most routine events (falling asleep, preparing coffee) the spectator comes to inhabit their subjectivity. The film thus fuses two points of enunciation usually separated - that of the subjects/objects of the film, those who supposedly experience without reflection, and that of the directors "supposed to know" and positioned to reflect with a distanced intelligence. The most minimalist of the Carandiru films in terms of performance and acting, performance in Prisioneiro is limited to what Ismail Xavier calls the camera-effect or "process of theatricalization generated by the camera and the real instigated by the experience of the filming itself with its consequences for all those involved."

In a kind of mise-en-abyme of collective authorship, Prisioneiro foregrounds subaltern agency by showing the prisoner-filmmakers in the act of filming, often in pairs. The prisoners are so much at ease, so convinced that the director is not an agent of the state, that they proudly display even their illegal activities, such as making rum, planting marijuana, and fabricating weapons. (If Babenco's perspective is creepily voyeuristic, that of the prisoner-cineastes is proudly exhibitionistic). Prisioneiro offers a strong case of what Comolli, borrowing from Claudine de France, calls “auto-mise-en-scène," the process by which the desire of the filmed subject comes to inform the mise-en-scène. Yet the prisoners are not angelized either by the director or by themselves; rather than heroes, they are complex, fully human subjects. At the same time, the film makes us aware of the limits of "giving voice," since at any given moment, due to what Consuelo Lins and Claudia Mesquita call the imbrication of perspectives, we are often not completely sure who filmed what we are 
ano 2 número 4

Dossiê

seeing (2008: 40). So Sacramento gives the camera to the prisoners, but also reveals the limits of this democratizing gesture.

Prisioneiro das Grades de Ferro can be seen as a culmination of a inexorable trend toward the democratization of filmic authorship. Although filmmaking historically has usually been in the hands of middle-class directors equipped with symbolic cultural capital (Bourdieu) and access to literal capital, many countervailing projects have tried to place the camera in the hands of the disempowered. Although this (partial) transfer of power was extremely difficult when filmmaking equipment was cumbersome and expensive, the various technological advances - from lightweight cameras and sound recording equipment in the 1960s to video in the 1980s up through the various digital revolutions - have made it infinitely easier.

Jean Rouch was an early key figure in this mutation toward egalitarian film production. Although Rouch-style collaboration now seems somewhat limited in the light of subsequent developments, it still constituted a major change in approach. Rouch spoke of “shared anthropology," i.e., a dialogic collaboration between filmmaker-ethnographer and the ethnographic subject (a sharing both reciprocated and reversed in Manthia Diawara's wittily titled film portrait Rouch in Reverse). With Rouch, democratization took many concrete forms, beginning with improvisation by the filmed subjects, for example Oumarou Gando as "Edward G. Robinson" improvising his commentary for Moi Un Noir, which reportedly inspired Belmondo's nonchalant improvisations in Godard's A Bout de Souffle. Another major democratizing change consisted in participant feedback in the form of screenings where the subjects offered their commentary and critiques, some included, for example in Chronique d'un Ete, in the final film itself.

Many of the "rules" articulated in Rouch's 1973 book The Camera and Man work toward the same democratizing effect. Rouch's goal of living with the subjects prior to filmmaking fosters more intimacy with the filmed subjects. The production ideals of minimal crew and hand-held equipment make film productions less intimidating by minimizing intrusion into the subjects' 
everyday lives. Rouch's option for minimal voice-over, meanwhile, downplays omniscient commentary in favor of the words of the actual participants, while the rejection of the zoom-lens was designed to minimize the symbolically predatory violence of ethnographic voyeurism.

More thoroughgoingly radical attempts at democratization go back to the many leftist collectives of the late 1960s, whether Cine-Liberation in Argentina or Third World Newsreel in the US, or S.L.O.N. and Cine-Lutte and Groupe Medvekine in France. We find a precursor in the form of the cinetracts, or militant short $16 \mathrm{~mm}$ black-and-white films by anony mous collectives treating the 1968 "events of May" in France. The cine-tracts orchestrated still photos of demonstrations, the recorded sounds of militancy, voice-over commentary, and the slogans of the day. One of the most famous cine-tracts -dubbed imagetexts by W. J. T. Mitchell - featured a Parisian graffito equating the CRS (de Gaulle's militia) with the Nazi SS (apud HABIB, 2008: 76). Chris Marker was a key figure in the largely student-led cine-tract movement, and a guiding force in the attempts to "put cameras in the hands of the workers," through his efforts with SLON (Society for the Creation of New Works) in collaboration with French factory workers.

Cinema was intimately involved in May 68, the near-revolution in France largely led by young people, beginning with L'Affaire Langlois, the February protests against the government's removal of Henri Langlois as head of the French cinematheque. In May, 1968, many French filmmakers called for the closing of the Cannes Film Festival in the name of solidarity with striking students and workers. Calling up the memory of the French revolution and the "three estates" (nobility, clergy, and the people), leftist filmmakers tried to create a cinematic equivalent through the short-lived Etats Generaux du Cinema, which audaciously proposed the complete abolition of censorship, free movie screenings, state support for non-commercial films, universal education in filmmaking, and more generally a cinema unencumbered by the profit motive.

A shift in attention from texts to their authorship and their collaborative production triggers a theoretical shift. The question of the mimetic real gets displaced onto the very different register of who is empowered to represent, 
ano 2 número 4

Dossiê

or stage, or even interrogate the real. Rather than verisimilitude, the issue becomes one of who is actually holding the camera and doing the editing. At the same time, the act of "giving voice" is very complicated. The phrase itself implies that one person or group possesses voice and then delegates it to an oppressed person or group. "Giving voice" is rooted in a charitable conception: the haves "give" to the representational "have nots," while the haves maintain their economic dominance, cultural capital, and paternalistic superiority. The real question, to use terms from Spinoza, is to turn potenza (power over) into potere (power as agency). In the cinema, it has never been simply a question of handing over the camera to representatives of the disempowered group. In the 1970s, different directors took different positions on the question of voice. For Chris Marker, placing cameras in the hands of workers would inevitably lead to a more accurate and politically coherent representation that would reveal, if not the truth, at least the provisional truth of a working class perspective. For the more skeptical Godard, such a handover would result only in a kind of pathetic mimicry rooted in false consciousness, whereby, in a circular process, workers would imitate those actors, such as Jean Gabin, who had incarnated workers in the cinema, and thus produce an imitation of an imitation.

In Japan, meanwhile, the films of Shinsuke Ogawa also have a place in this history. Ogawa's roughly 25 films, made between the 1950s and 1990s, are embedded documents of the postwar Japanese left, from radical student movements, to the long, violent resistance of farmers to the construction of the Narita airport in the early 1970s, and then to Japan's rural north, where Ogawa and his crew learned farming techniques and taught filmmaking, initiating a hybrid collective practice in which the documentary subject and filmmaking crew become all but indistinguishable. ${ }^{8}$ But it is perhaps the post-Cinema Novo history of Brazilian cinema that most dramatically exemplifies the dramatic shift from representation to self-representation. While the Cinema Novo directors were all white middle-class heterosexual male urban intellectuals "speaking 
for" the marginalized masses, Brazilian directors are now women, gays, lesbians, blacks, and indigenous. This paradigm shift is reflected not only in the trajectories of individual directors such as Coutinho, but also revealed through a comparison of two versions of the same film project, one from 1962 and the other from 2010. The initial project, called Cinco Vezes Favela, was a five-episode film centered on the Rio favelas, directed by Cinema Novo directors like Leon Hirszman and Carlos Diegues. The 2010 remake, in contrast, was produced by Diegues but filmed by directors from the favelas (Manaira Carneiro, Wagner Novais, Rodrigo Felha, Cacau Amaral, Cadu Barcelos, and Luciana Bezerra). The revelatory new title: Cinco Vezes Favela: Agora Por Nós Mesmos.

Many zigzags marked the slow movement toward self-representation. First came a theoretical critique of documentary itself. In 1972 Arthur Omar published a manifesto defending the "anti-documentary," or films which problematized the paternalism of the leftist documentaries of the time. Eduardo Coutinho's Cabra Marcado para Morrer (Twenty Years After, 1984), registers this representational shift as it stood at the time of the political "opening" of the mid-1980s. Coutinho's initial plan, conceived in optimistic left-populist years before the 1964 coup d'etat, was a kind of cine-resgate or recovery of history, which would dramatically reconstruct the real-life political assassination, in 1962, of peasant leader João Pedro Teixeira. In a gesture of actantial selfrepresentation, the actors were to be the actual participants (João Pedro's comrades), the locale was to be the actual events, and one of the "actors" would be the deceased leader's widow Elizabete, playing herself. Interrupted by the "risk of the real" in the form of the 1964 coup d'etat, the filmmakers and the peasant participants were dispersed, and the material already shot had to be hidden from the dictatorship. With political liberalization 20 years later, Coutinho sought out the footage and the participants. Thanks to the film, Elizabete emerges from underground, encounters her family, and recomposes her identity as person and activist.

What interests us here, however, is the film's reflexive charting of a mutation in representational practice. Between Cabra in 1964 and Cabra 1984, a radical change in filmic treatment exemplifies what one might call the historicity of 
ano 2 número 4

Dossiê

stylistics. The 1960s meeting with the widow is rendered in the didactic manner of the period - a mélange of Salt of the Earth-style socialist realism, stilted performance, over-explicit dialogue, and the heroicized image of the "people" promoted by the leftist Centers for Popular Culture. The 1980s meeting, in contrast, takes place in the era of network TV and the evolving style of Brazilian TV reportage. Coutinho shows photographs to his subjects, where their own image provokes recollections and emotions. In a kind of experiential photogenie - Jean Epstein's phrase for the fascination of the filmed face -the film shows the conflicted emotions of love and loss and anger as they play across Elizabeth's face. The filmic language, two decades later, is less inclined to discourse omnisciently about the other, more inclined to listen and learn.

In the wake of Cabra Marcado, Coutinho continued his unending search for more open and democratic forms of filmmaking. Consistent with his refusal of paternalism, miserabilism, and moralism, Coutinho distinguishes between the interview - premised on formal distance and social hierarchy - and the conversation, premised on intimacy, relative equality, and openness to digression. Rather than make films about others, Coutinho makes films with others. His constantly developing capacity for listening intensifies the desire of the filmed subjects to speak. In this sense, Coutinho develops what might be called, playing on Bakhtin, a filmic grammar of listening, or what Comolli synaesthetically calls the listening camera. Coutinho's work, in this sense, explores the various dimensions of speech tact with a view toward egalitarian interlocution.

For Consuelo Lins, Coutinho's films constitute embodied theory, where theorization is consubstantial with and tested by filmic praxis. The search now is less for story and character than for an illuminating premise or provocative concept. Within this alternative poesis, Brazilian analysts have noted certain general traits, including: 1) spatial concentration, an option to explore a single locale (the favela Babilônia) or even a single apartment building (Edifício Master); 2) the on-screen display of the apparatus and the filmmaking team; 3) aesthetic minimalism (no non-diegetic music, sparing use of montage and voice-over); 4) leisurely duration, sufficient for the subject to be at ease and expose his or her 
hidden transcripts (proscribed non-official thoughts and feelings) (SCOTT, 1990: 34); 6) no prior scripting to avoid pre-set agendas; 7) single encounters with the filmed subject, without the luxury of "rewriting;" 8) the option for listening as opposed to combative directorial assertions; and 9) the refusal of totalization, an emphasis on singular human subjects traversed by contradictory social forces rather than on individuals as specimens of a pre-existing sociological or ideological category ("the working class," "typical umbanda practitioner). ${ }^{9} \mathrm{The}$ result of all these procedures is what Xavier calls the "aesthetically-inflected auto-construction of the character" (MIGLIORIN, 2010: 78).

Indigenous media in Brazil also merits mention as part of this trajectory of democratization. Indigenous films challenge the dominant western aesthetic not in the sense of producing films that are more aesthetically daring than those of a Godard or a Kluge but rather in the sense of making manifest the collective cultural assumptions that undergird indigenous poesis. Indigenous media begins from a taken-for-granted communalism where the filmmakers are assumed to be speaking not for themselves but for their communities. Ginsburg speaks of "embedded aesthetics," in which the imperatives of the community overwhelm individual artistic distinction, a "system of evaluation that refuses a separation of textual production and circulation from broader arenas of social relation” (1994: 368). Unlike the French New Wave, with its Oedipal ressentiment against "le cinema de papa," the indigenous filmmakers, within a kind of tribal auteurism, see themselves as primarily accountable to family and clan rather than to producers or sponsors. They consciously seek the approval of the elders, who insist on certain civilities, for example that the "characters" not be interrupted in mid-speech. Both the elders and their juniors see film as a way to preserve the traditional corpus of songs and stories.

9. The noteworthy analysts of Coutinho's work include Consuelo Lins (O Documentario de Eduardo Coutinho: Televisao, Cinema, e Video), Carlos Alberto Mattos (Eduardo Coutinho: O Homem que caiu na Real) and Luiz Zanin Oricchio (Cinema de Novo: Um Balanço Crítico da Retomada). On Brazilian documentary in general, see also the excellent essays by Andrea França, Cesar Guimarães, Claudia Mesquita, Ivana Bentes, José Carlos Avellar, Miguel Pereira and Mariana Baltar in MIGLIORIN, Cezar (org.). Ensaios no Real and also ANDERMANN, Jens; BRAVO, Alvaro Fernandez (orgs.) New Argentine and Brazilian Cinema: Reality Effects. 
We find a different approach to the indigenous theme in Brazilian filmmaker Sergio Bianchi's deconstructive documentary Mato Eles? (Should I Kill Them, 1983) . The film critiques the usual sentimental approach to the Brazilian Indians, beginning with the title, where the shifter pronoun "I" could refer either to the director or to the Indians - "Should I (the white) kill the Indians?" Or "Should I (the Indian) kill the whites?" The very formulation mocks white Brazilian sentimentality about "our Indians." The relationship is no longer cordial; rather, it is a struggle to the death. Instead of the customary depiction of the local habitat, interspersed with talking-head interviews and disembodied voice-overs expressing the enlightened humanism of middle-class white filmmakers, Bianchi mocks both the official discourse concerning the Indian and the bourgeois bonne conscience of the denunciation documentary. As a form of parodic pedagogy, Mato Eles? is structured around a series of apparently whimsical multiple-choice quizzes addressed to the spectator. The Brechtian call for the active spectator who "renders a verdict" is tinged here with bitter irony. One question reads:

\footnotetext{
Very few Indians remain from the once numerous Xeta tribe. What happened to the others? Choose one of the following: 1) They all intermarried with the white population and are living in the cities; 2) They all died due to infection diseases and litigation concerning land rights; 3) They are all on vacation in Europe; 4) the Xeta never existed, This documentary is false; 5) All of the above are correct.
}

Another quiz poses three unpalatable but hardly impossible outcomes: "The extermination of the Indians should be a) immediate; b) slow; c) gradual." Leaving little space for spectatorial self-satisfaction or false optimism, the quiz confronts the audience with the reality of extermination in a manner than initially provokes laughter yet subsequently elicits reflection and self-doubt.

Mato Eles? mocks the traditional romantic-indianist exaltation of the "disappearing" Indian by revealing that the "brave warriors" of the $19^{\text {th }}$ century romantic poets are now trapped in a dreary $20^{\text {th }}$ century cycle of impoverished powerlessness. At one point, Bianchi gives us a satiric trailer announcing 
an Indianist epic entitled, in homage to James Fenimore Cooper, The Last of the Xeta. The lush strains of the Brazilian Indianist opera $O$ Guarani, by the "Brazilian Verdi" Carlos Gomes, swell our expectations for an epic-romantic spectacle. Instead, Bianchi shows us a series of photographs of the sole surviving member of the tribe. The brave warrior of romanticism has become the object of police-style mug shots coldly registering the human remainders of genocide. Nor does Bianchi exempt himself from criticism. In a case of financial reflexivity, a gnarled-face Guarani asks Bianchi how much money he will make on the film, an unflattering question that would normally have found its way to the editingroom trash can. An authorial voice-over then speculates about the myriad ways of financially profiting from the Indian - anthropological scholarships, coffee table photo-albums, indigenous arts and crafts shops, European tours for the films. Here voice-of-God commentary mocks the filmmaker-God himself, in an act of self-desacralization directed at the power structure, the canonical documentary, and the cineaste himself. 


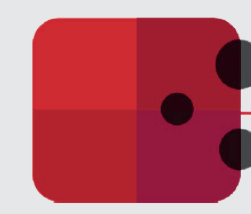

ano 2 número 4

Dossiê

\section{References \\ References}

AUFERDEIDE, Patricia. Documentary Film: A Very Short Introduction. New York: Oxford, 2007

BERNARDET, Jean-Claude. Cineastas e Imagems do Povo. São Paulo: Cia das Letras, 2003

COMOLLI, Jean-Louis. Corps et Cadre: Cinema, Ethique, Politique. Paris: Verdier, 2012

COMOLLI, Jean-Louis. Voir et Pouvoir. Paris: Editions Verdier, 2008

DAY, Amber, Satire and Dissent. Bloomington: Indiana University Press, 2011

DELEUZE, Gilles. L'Image-Temps. Paris: Minuit, 1985

DERRIDA, Jacques. “The Law of Genre” Glyph: Textual Studies, n. 7, 1988

FOUCAULT, Michel. "Intellectuals and power: A conversation between Michel Foucault and Gilles Deleuze" in Michel Foucault, Language, Counter-Memory, Practice: Selected Essays and Interviews. Ithaca, N.Y.: Cornell University Press, 1980

GINSBURG, Faye. "Embedded Aesthetics: Creating a Discursive Space for Indigenous Media”. Cultural Anthropology, v. 9, no. 3, 1994

HABIB, Andre. Chris Marker et l'imprimerie du regard. Paris: L'Harmattan, 2008

JAMES, David E. Allegories of Cinema. Princeton: Princeton University Press, 1989

LINS, Consuelo Lins; MESQUITA, Claudia. Filmar O Real. Rio: Zahar, 2008

MIGLIORIN, Cezar (org.). Ensaios no Real. Rio: Azougue, 2010

ODIN, Roger. De la Fiction. Bruxelles: De Boeck, 2000

RANCIÉRE, Jacques. La Fable Cinematographique. Paris: Seuil, 2001

SOBCHAK, Vivian Carnal Thoughts: Embodiment and Moving Image Culture. Berkeley: University of California Press, 2004

SCOTT, James C. Domination and the Arts of Resistance: Hidden Transcripts. New Haven: Yale University Press, 1990 
WHITE, Hayden. Metahistory: The Historical Imagination in Nineteenth Century Europe. Baltimore: Johns Hopkins, 1973

WINSTON, Brian. “Rouch's 'Second Legacy': Chronique d'un Ete as Reality TV's Totemic Ancestor". In: TEN BRINK, Joram. Building Bridges: The Cinema of Jean Rouch. London: Wallflower, 2007 